\title{
Relationship of HBeAg Status with ALT DNA Level and Liver Histology in Chronic Hepatitis B Patients
}

\author{
Kronik Hepatit B Hastalarında HBeAg Durumunun ALT, DNA Düzeyi ve Karaciğer \\ Histolojisi ile llișkisi
}

\author{
Ayşe INCI1, Muzaffer FINCANCI2, Utku Murat KALAFAT3 \\ ${ }^{1}$ Kanuni Sultan Süleyman Education and Research Hospital, Department of Infectious Disease and Clinical Microbiology, Istanbul, Turkey \\ 2Istanbul Education and Research Hospital, Department of Infectious Disease and Clinical Microbiology, Istanbul, Turkey \\ 3Kanuni Sultan Süleyman Education and Research Hospital, Department of Emergency Medicine, Istanbul, Turkey
}

\begin{abstract}
Objective: Chronic hepatitis $\mathrm{B}(\mathrm{CHB})$ infection is a highly prevalent and important health problem. Hepatitis B virus (HBV) infection is a very important public health problem in our country. Our country is in a mid-hepatitis B virus-endemic area. Hepatitis B virus (HBV) is enveloped DNA virus which causes acute and chronic infections. Liver biopsy is the gold standard procedure for documenting liver damage in chronic hepatitis. In this study, our aim was to determine the relationship of positive or negative $\mathrm{HBeAg}$ status in chronic hepatitis B patients with ALT (alanine aminotransferase), DNA level and liver histology.

Materials and Methods: We retrospectively evaluated medical records of 230 hepatitis B patients who underwent liver biopsy in our clinic. Demographic properties, biopsy results, liver enzymes, HBV DNA levels and serological indications were evaluated. HBV DNA was investigated by quantitation of DNA using realtime polymerase chain reaction (PCR) and serological markers by enzyme immunoassay (EIA). Patients were separated into 2 groups according to their $\mathrm{HBeAg}$ status (group 1= HBeAg-positive; group $2=\mathrm{HBeAg}$-negative).

Results: Two hundred and thirty patients participated in the study. The average age of patients in group 1 and group 2 was $36.42 \pm 11.76$ and $47.01 \pm 12.15$, respectively. There was a statistically significant difference in average age between the groups $(p<0.000)$. The average ALT level was higher in HBeAg-positive group $(p<0.000)$. There was no significant difference in fibrosis score between the groups, however, histologic activity index (HAl) was higher in group 2 than in group 1. When the correlation between ALT and HAI was evaluated, a significant and positive correlation was found only in $\mathrm{HBeAg}$ negative-patients while no significant correlation could be detected between ALT and fibrosis in both groups. There was not any significant correlation between DNA and fibrosis in group 1 while positive correlation was detected in group 2 .

Conclusion: We assume that when evaluating HBV infections, serological tests, HBV DNA level, liver enzymes, previous treatments and clinical status of the patient should be considered as a whole. Key Words: Hepatitis B virus, DNA, biopsy
\end{abstract}

\section{ÖZET}

Amaç: Kronik hepatit B (KHB) enfeksiyonu tüm dünyada ve ülkemizde oldukça yaygın ve önemli bir sağlık sorunudur. Hepatit B virüs (HBV) enfeksiyonu ülkemiz için önemli bir sağlık sorunu olusturmaktadır. Ulkemiz HBV enfeksiyonları yönünden orta endemik bölgede yer almaktadır. HBV'ler, akut ve kronik enfeksiyonlara neden zarflı DNA virüslerdir. Karaciğer biyopsisi kronik hepatit hastalığında karaciğer hasarı göstermek için altın standarttır. Bu çalışmada amacımız kronik hepatit $B$ hastalarında $\mathrm{HBeAg}$ pozitif ve negatiflik durumunun ALT (alanin aminotransferaz) DNA düzeyi ve karaciğer histolojisi ile ilişkisinin belirlenmesidir.

Gereç ve Yöntemler: Kliniğimizde takip ve tedavi edilen, kronik hepatit B olguları arasında karaciğer biyopsisi yapılan 230 hastanın dosyası retrospektif olarak incelendi. Hastaların demografik özellikleri biyopsi sonucları karaciğer enzimleri, HBV DNA düzeyleri ve serolojik göstergeleri değerlendirmeye alındı. HBV DNA kantitatif olarak real time polimeraz zincir reaksiyonuyla (PCR), serolojik testler ise enzim immuno assay (EIA) yöntemiyle çalıșımıștır. Calıșmaya alınan hastalar $\mathrm{HBeAg}$ durumlarına göre 2 gruba ayrıldı (grup 1 = HBeAg pozitif; grup $2=\mathrm{HBeAg}$ negatif).

Bulgular: Bu çalışmaya toplam 230 alındı. Olguların \%77'si HBeAg negatifti. Çalışmaya alınan hastaların yaş ortalamasına bakıldığında yaş ortalaması grup 1'de $36,42 \pm 11,76$ ve grup 2'de $47,01 \pm 12,15$ idi. Bu sonuç istatistiksel olarak anlamlı bulundu $(p<0,000)$. ALT ortalaması gruplara göre bakıldığında HBeAg pozitiflerde daha yüksekti $(p<0,000)$. Fibrozis skoru açısından gruplar arasında anlamlı bir fark bulunmazken, histolojik aktivite indeksi (HAl) HBeAg negatif olgularda daha yüksekti. ALT ile HAl arasındaki korelasyon değerlendirildiğinde sadece $\mathrm{HBeAg}$ negatif hastalarda anlamlı, pozitif yönde korelasyon bulunurken ALT ile fibrozis arasında her iki grupta da anlamlı bir korelasyon yoktu. DNA ile $\mathrm{HAl}$ arasındaki korelasyon değerlendirildiğinde sadece $\mathrm{HBeAg}$ negatif hastalarda anlamlı, pozitif yönde korelasyon bulundu. DNA ile fibrozis arasında 1. grupta anlamlı bir korelasyon yoktu, 2. grupta ise pozitif korelasyon tespit edildi.

Sonuç: Sonuç olarak, HBV enfeksiyonlarını değerlendirirken hastanın serolojik testleri, HBV DNA düzeyi, karaciğer ezimleri, hastanın tedavi alıp almadığı ve hastanın klinik durumu bir bütün olarak değerlendirilmesi gerektiğini düşünmekteyiz.

Anahtar Kelimeler: Hepatitis B virüs, DNA, biyopsi 


\section{Introduction}

Chronic hepatitis B virus (HBV) infection is an important, widespread health problem. Approximately, 600.000 people die of liver failure, cirrhosis, and hepatocellular carcinoma (HCC) every year (1). Currently, it is possible to diagnose and follow patients with confidence by monitoring various parameters of hepatitis (2).

Four stages of chronic HBV infection include immune tolerance, immune clearance (response), inactive carrier state, and reactivation. The immune response stage shows active inflammation in the liver biopsy and increasing enzyme levels with liver damage. During this period, the patient has hepatitis $\mathrm{B}$ e antigen ( $\mathrm{HBeAg}$ )-positive chronic B hepatitis (3).

Chronic HBV infection can be $\mathrm{HBeAg}$ positive or negative. Patients are $\mathrm{HBeAg}$-positive in the early stages of chronic hepatitis $\mathrm{B}$ and become HBeAg-negative in the advanced stages. The number of $\mathrm{HBeAg}$-negative cases has increased over the last 10 years as a result of aging HBV-infected population (4). Most HBeAg-negative chronic HBV screening has been conducted in the Mediterranean region, although it has increased worldwide (5).

During patient monitoring, it is necessary to discuss the biochemical, virological, and clinical features separately according to the e antigen status (6).

The serum transaminase levels can increase at different rates because of the damage to the liver parenchyma. Measurement of aspartate transaminase (AST) and alanine aminotransferase (ALT), indicators of inflammation, is an inexpensive test and frequently used in the clinical practice (7).

Liver biopsy is the gold standard for following and treating chronic HBV. The modified histologic activity index (HAl), necroinflammatory activity, and prevalence of fibrosis are evaluated separately. The modified HAl is scored as follows: 0) no fibrosis, 1) fibrous expansion in some portal areas, with or without short fibrous septa, 2) fibrous expansion in most portal areas, with or without short fibrous septa, 3) fibrous expansion in most portal areas and rare portal-portal (P-P) bridge formation, 4) fibrous expansion in portal areas and obvious bridge formation, 5) obvious bridge formation and rare nodules, and 6) potential or definite cirrhosis (8).

This study determined the relationships of positive and negative HBeAg status in chronic hepatitis B patients with ALT and DNA levels and liver histology.

\section{Materials and Methods}

This retrospective study enrolled 230 chronic hepatitis B patients who were treated and followed at Istanbul Education and Research Hospital, Department of Infectious Disease and Clinical Microbiology and underwent liver biopsy. The included patients were known to be HBsAg-positive for more than 6 months, had not been treated before the biopsy, and were not co-infected with hepatitis $\mathrm{C}$ virus (HCV) or human immunodeficiency virus (HIV).

Patient age, gender, biopsy results, liver enzyme levels before the biopsy, HBV DNA levels, and serological indicators were evaluated. Liver histology was evaluated by pathologists using the Ishak scoring system. The patients were divided into HBeAgpositive (group 1) and HBeAg-negative (group 2) groups.

Student's t-test was used to compare the means between the groups. The relationships between the histopathological findings and the ALT and DNA levels were evaluated using Spearman's correlation coefficient. Statistical significance was taken as $p<0.05$.

\section{Results}

The study enrolled 230 patients: 177 (77\%) were HBeAgnegative and 53 (23\%) were HBeAg-positive. The mean age of the $\mathrm{HBeAg}$-negative patients was significantly higher than the $\mathrm{HBeAg}$ positive patients $(36.42 \pm 11.76$ vs. $47.01 \pm 12.15$ years; $p<0.000)$. The mean ALT level was higher in the HBeAg-positive group (129.03 \pm 89.62 vs. $76.35 \pm 75.06$; $\mathrm{p}<0.000)$. The $\mathrm{HAl}$ was higher in the $\mathrm{HBeAg}$-negative subjects $(6.25 \pm 2.3$ vs. $7.39 \pm 2.88 ; p=0.004)$ (Table 1). There was no significant difference in the fibrosis score between the groups (1.81 \pm 1.06 vs. $2.11 \pm 1.19 ; p=0.098$ ).

A significant positive correlation was found between ALT and $\mathrm{HAl}$ only in the HBeAg-negative patients $(p=0.005, r=0.209)$. No significant correlation was found between ALT and fibrosis. A significant positive correlation between DNA and HAl was found only in the HBeAg-negative patients $(p=0.007, r=0.201)$. No significant correlation was found between DNA and fibrosis in group 1, while a positive correlation was found in group $2(p=0.011$, $r=0.191$; Table 2).

\section{Discussion}

The natural course of chronic HBV infection and disease is complicated and quite variable (9). Over all age groups, $2-10 \%$ of acute HBV infection progresses to chronic infection. Chronic HBV infection is an important risk factor for hepatocellular cancer (HCC),

Table 1. Biochemical, virological and histopathological findings in our cases

\begin{tabular}{|l|l|l|l|}
\hline Parameter & $\begin{array}{l}\text { HBeAg-positive } \\
(\mathbf{n}=53)\end{array}$ & $\begin{array}{l}\text { HBeAg-negative } \\
(\mathbf{n}=177)\end{array}$ & $p$ \\
\hline Age & $36.42 \pm 11.76$ & $47.01 \pm 12.15$ & 0.000 \\
\hline ALT & $129.03 \pm 89.62$ & $76.35 \pm 75.06$ & 0.000 \\
\hline DNA & 44.140 .485 & 12.327 .270 & 0.001 \\
\hline $\begin{array}{l}\text { HAI } \\
\text { (mean) }\end{array}$ & $6.25 \pm 2.35$ & $7.39 \pm 2.88$ & 0.004 \\
\hline $\begin{array}{l}\text { Fibrosis } \\
\text { (mean) }\end{array}$ & $1.81 \pm 1.06$ & $2.11 \pm 1.19$ & 0.098 \\
\hline
\end{tabular}

Table 2. Correlation of the DNA and ALT levels with liver histology

\begin{tabular}{|l|l|l|l|l|}
\hline & \multicolumn{2}{|l|}{ HBeAg-positive $(n=53)$} & \multicolumn{2}{l|}{ HBeAg-negative $(n=177)$} \\
\hline & $r$ & $p$ & $r$ & $p$ \\
\hline ALT-HAI & 0.054 & 0.700 & 0.209 & 0.005 \\
\hline ALT-fibrosis & 0.019 & 0.891 & 0.053 & 0.482 \\
\hline DNA-HAI & 0.053 & 0.707 & 0.201 & 0.007 \\
\hline DNA-fibrosis & 0.055 & 0.691 & 0.191 & 0.011 \\
\hline
\end{tabular}




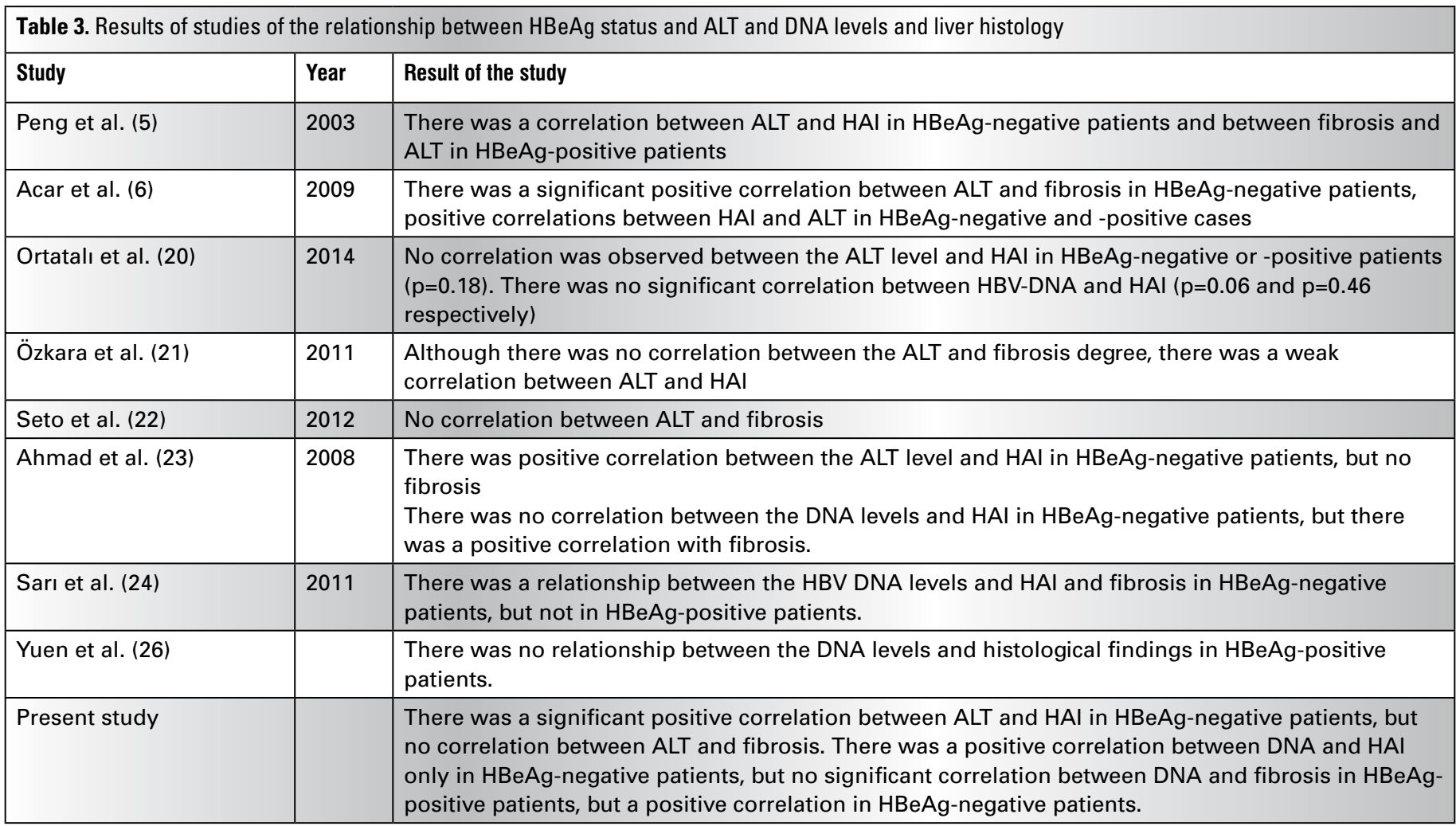

especially in patients with cirrhosis. Their HCC risk is increased 390-fold when compared with the normal population (10).

To treat chronic HBV infection appropriately, the stage of the disease must be known and HBV DNA and ALT levels are important parameters in the treatment approach (11).

In our series, $77 \%$ of the subjects were HBeAg-negative. In other studies, the proportion of HBeAg-negative cases ranged from 16.4 to $76.7 \%(5,6,12,13,14,15,16,17,18,23,25)$.

Comparing $\mathrm{HBeAg}$-positive and -negative patients, the latter tended to be older, had a higher HAl, and lower average ALT and DNA levels. There was no significant difference in the mean fibrosis score between the groups.

Peng et al. (5) observed that HAl was significantly higher in $\mathrm{HBeAg}$-negative subjects, while the ALT levels were lower, albeit not significantly. Our results are compatible with these results.

Acar et al. reported that the average age of HBeAg-negative patients was $25.87 \pm 5.99$ years and this was significantly higher than that of HBeAg-positive patients. They also reported lower ALT levels in HBeAg-negative patients, as in our study, and they found no significant difference in the mean fibrosis scores (6). However, the HAl scores in $\mathrm{HBeAg}$-negative patients and in $\mathrm{HBeAg}$-positive patients in their study was significantly different than those in our subjects $(4.06 \pm 2.02$ and $4.78 \pm 2.40$ vs. $6.25 \pm 2.3$ and $7.39 \pm 2.88)$ $(\mathrm{p}=0.001)$.

Yalçın et al. (17) found no significant difference in the HBeAg status and fibrosis scores in HBeAg-negative and -positive subjects, as in our study, but found higher HAl scores in HBeAg-negative patients.

In our study, the DNA level was significantly higher in the $\mathrm{HBeAg}$-positive patients compared with the HBeAg-negative group, as in other studies $(17,19,20)$.
We observed that the ALT and DNA levels were not correlated with the histopathological findings in the HBeAg-positive patients, although the DNA level was higher than in HBeAg-negative cases; the $\mathrm{HAl}$ and fibrosis scores also increased and the ALT level was correlated with the HAl, but not with the fibrosis scores (Table 3).

The changes in the ALT and DNA levels are an important indicator of histopathological activity for diagnosing cirrhosis and HCC stage. We believe that serological tests, HBV DNA level, liver enzymes, and the clinical status of the patient must be evaluated regardless of whether the patient receives therapy or not.

Ethics Committee Approval: None, Informed Consent: Consent form was filled out by all participants, Concept: Ayşe Inci, Muzaffer Fincancı, Utku Murat Kalafat, Design: Ayşe Inci, Utku Murat Kalafat, Data Collection or Processing: Ayşe Inci, Utku Murat Kalafat, Analysis or Interpretation: Ayşe Inci, Muzaffer Fincancı, Utku Murat Kalafat, Literature Search: Ayşe Inci, Utku Murat Kalafat, Writing: Ayşe Inci, Peer-review: External and internal peer-reviewed, Conflict of Interest: No conflict of interest was declared by the authors, Financial Disclosure: The authors declared that this study has received no financial support.

\section{References}

1. World Health Organization. Hepatitis B vaccines. Wkly Epidemiolo Rec.No. 40, 2009, 84, 405-420.

2. Tosun S. Metanalysis of hepatitis B epidemiyology puplishes. Tabak F, Tosun S.(eds) Viral Hepatit 2013. Istanbul: Istanbul Medical Publishing, Association of Fighting with Viral Hepatitis, 2013:25-81.

3. Sonsuz A. Chronic Hepatitis B and C.I.U Cerrahpasa Medical Faculty Continuing Medical Training Activiy Symposym Series No:58, November 2007; p.79-90. 
4. Zarski JP, Marcellin P, Leroy V, Trepo C, Samuel D, GanneCarrie N, Barange K, Canva V, Doffoel M, Cales P; Fédération nationaledes Pôles de référence et des Réseaux Hépatites. Characteristics of patients with chronic hepatitis B in France: predominant frequency of $\mathrm{HBe}$ antigen negative cases. $\mathrm{J}$ Hepatol. 2006; 45:355-360.

5. Peng J, Luo K, Zhu Y, Guo Y, Zhang L, Hou J. Clinical and histological characteristics of chronic hepatitis $B$ with negative hepatitis B e-antigen. Chin Med J (Engl). 2003;116:1312-1317.

6. Acar A, Turhan V, Karacaer Z, Öncül O, Görenek L. Correlation of $\mathrm{HBeAg} / \mathrm{Anti}-\mathrm{HBe}$ status with liver histology and ALT/AST levels in young adult hepatitis B patients. AJC. 2009:3:231-234

7. Pehlivan $Y$, Koruk M, Gülşen MT, Savaş $C$, Kadayıfçı $A$. The Relation Between AST/ALT ratio and stage of the disease in chronic hepatitis. Gaziantep Medicine Journal. 2008;14:28-31.

8. Aydın O,Yıldız L, Kefeli M, Barış S, Kandemir B. Reproducibility of ishac modified histological activity index between one an multi observer at chronical viral hepatitis. Turkish Pathology Journal. 2005;21:58-61.

9. Fattovich G, Bortolotti F, Donato F. Natural history of chronic hepatitis B: special emphasis on disease progression and prognostic factors. J Hepatol. 2008;48:335-352.

10. Gürbüz AK. Getting chronical at hepatitis B virüs - Clinic and ordinary course at hepatitis Updated. Gastroentherology. 2003;7:50-54

11. Leblebicioğlu H. Checking index of chronical hepatit treatment. In: Tabak F, Tosun S (eds). Viral Hepatit 2013. Istanbul: Istanbul Medical Publishing: Association of Fighting with Viral Hepatitis; 2013: p.303-307.

12. Ridruejo $E$, Marciano $S$, Galdame $O$, Reggiardo MV, Muñoz AE, Adrover R, Cocozzella D, Fernandez N, Estepo C,Mendizabal M, Romero GA, Levi D, Schroder T, Paz S, Fainboim H, Mandó OG, Gadano AC, Silva MO. Efficacy and safety of long term entecavir in chronic hepatitis B treatment naïve patients in clinical practice. Ann Hepatol. 2014;13:327-336.

13. Chan HL, Leung NW, Hussain M, Wong ML, Lok AS. Hepatitis $B$ e antigen-negative chronic hepatitis $B$ in Hong Kong. Hepatology. 2000;31:763-768.

14. Aygün C,Gözel N, Demirel U, Yalnız M, Özercan IH, Bahçecioğlu $\mathrm{IH}$. Relation of liver fibrosis with serum GGT level at chronical viral hepatitis B diagnosed patient. Frrat Medical Journal. 2010;15:74-78.

15. Demir NA,Kölgelier S, Demir LS, Sümer Ş,Dikici N, Özçimen $S$, Inkaya AÇ. Evaluation of treatment result with $245 \mathrm{mg} /$ day tenofovir Disoproksil Fumarat for one year at hepatitis B patients. Nobel Med.2013;9:57-62.

16. Inci A, Fincanci M, Müderrisoğlu C. Investigation of antihepatitis delta virus and anti-hepatitis $C$ virus in patients with hepatitis B virus infection. Istanbul Med J. 2013;14:109-111.

17. Yalcin K, Degertekin H, Yildiz F, Celik Y. Markers of disease activity in chronic hepatitis B virus infection. Clin Invest Med. 2003;26:27-34.

18. Shao J, Wei L, Wang $H$, Sun $Y$, Zhang LF, Li J, Dong JQ. Relationship between hepatitis B virus DNA levels and liver histology in patients with chronic hepatitis B. World J Gastroenterol 2007;13:2104-24107.

19. Xie Y, Zhao H, Dai WS, Xu DZ. HBV DNA level and antigen concentration in evaluating liver damage of patients with chronic hepatitis B. Hepatobiliary Pancreat Dis Int. 2003;2:418422.

20. Ortatatı M, Gümral R, Özbek A, Kenar L. Relation between. liver damage and serum and tissue viral load and serology at hepatitis B patients. DOI: 10.4328/JCAM.1534.

21. Özkara S, Tosun I, Sari B, Kiliç G, Vardar Aker F, Sezikli M, Güzelbulut $F$, Bor $E$. The correlation of serum transaminase values with fibrosis staging and necroinflam-matory activity scores in chronic Hepatitis. Turkiye Klinikleri J Med Sciences. 2011;31:68-74.

22. Seto WK, Lai CL, Ip PP, Fung J, Wong DK, Yuen JC, Hung IF, Yuen MF A large population histology study showing the lack of association between ALT elevation and significant fibrosis in chronic hepatitis B. PLoS ONE. 2012;7:32622.

23. Ahmad N, Alam S, Mustafa G, Adnan AB, Baig RH, Khan M. e-antigen-negative chronic hepatitis $B$ in Bangladesh. Hepatobiliary Pancreat Dis Int. 2008;7:379-382.

24. Sari A, Dere Y, Pakoz B, Calli A, Unal B, Tunakan M. Relation of hepatitis $B$ core antigen expression with histological activity, serum HBeAg, and HBV DNA levels. Indian J Pathol Microbiol. 2011;54:355-358.

25. Kaya S, Yönem Ö, Özdemir L, Sümer Z. Relation between HBV serological indicators with HBV DNA quantity and serum alanine Inönü University Medical Faculty Journal 2006;13:2124

26. Yuen MF, Ng IO, Fan ST, Yuan HJ, Wong DK, Yuen JC, Sum SS, Chan AO, Lai CL. Significance of HBV DNA levels in liver histology of $\mathrm{HBeAg}$ and Anti-HBe positive patients with chronic hepatitis B. Am J Gastroenterol. 2004;99:2032-2037. 